International Economics

\author{
Vitalina KURYLIAK, \\ Bogdan LITOVCHENKO
}

\title{
FORMATION OF CREATIVE ORGANIZATION IN THE GLOBAL INFORMATION ENVIRONMENT
}

\begin{abstract}
The concept of organization as an organistical system facing the challenges of the creative economy is considered. It is grounded that the ideal creative organization with a high level of information will represent a certain symbiosis between organic and anarchic culture in the future. It is identified that with the emergence of virtual organizations, traditional elements of the organizational culture lose their value, while the informational technologies create opportunities for communication and collaboration, regardless of distance and borders. Thus, the basis for the virtual organizations creates their adaptability and transferability. Key requirements regarding the creative industry management organization are singled out as following: proactivity, strategic perspective, innovation, initiation of risk, modeling, experimentation and creativity, support of the independent business units' coordination. The model of organizations' types, which should reflect their organistical nature, strategic perspective and attitude to risk is presented. The main barriers that limit the ability of organizations to creativity - the lack of the innovative organizational culture as well as the lack of professional risk managers and analysts are outlined. However, these features have not yet organi-
\end{abstract}

(C) Vitalina Kuryliak, Bogdan Litovchenko, 2017.

Kuryliak Vitalina, Dr. of Econ. Sciences, Professor, Ternopil National Economic University, Ukraine. Litovchenko Bogdan, Cand. of Econ. Sciences, Assist. Prof., University of Customs and Finance, Dnipro, Ukraine. 
cally become peculiar by creative organizations, requiring the development of the appropriate business models culture.

\section{Key words:}

Creative economy, organistical system, organizational culture, creative organization, virtual organization, complexity of organization, integrity of organization, organic culture.

JEL: L29, M14, O15.

\section{Problem setting}

The emergence and development of the creative economy in modern society causes globalization challenges of the classic theory and practice of management. Creative Management is an instrument of efficient formation of a new socio-economic system. It is examined in the context of synergy, creativity, innovation and ethical business. That is why the main problems that need constant attention of the organization's management are: proactivity, strategic perspective, innovation, initiation of risk, modeling, experimentation and creativity, support of coordination of independent business units. Focus is also in the ideal construction of creative organizations with a high level of information that represents a certain symbiosis between organic and anarchic culture with overcoming their limitations.

2. The objective of the article. The study aims to identify the main principles of creative management for the modern organization and development of the concept of creative management, as well as characteristics of creative organization as a system in the historic retrospective. 


\section{Literature review}

Issues of creative economy development and implementation of management tools that would be adequate to the requirements of the modern society are in the focus of many researchers. Classical contributions of such researchers as R. Ackoff ${ }^{1}$ (Ackoff, 1985), I. Ansoff ${ }^{2}$ (Ansoff, 1989), P. Drucker ${ }^{3}$ (Drucker, 2000), R. Hall ${ }^{4}$ (Hall, 2001), A. Kredisov (Kredisov, 2009) investigate a socio-technical nature of management. R. Kilman (Kilman, 1985), K. De Witte (De Witte, 1999), H. Morgan (Morgan, 2011), J. Pennings (Pennings, 1987), O. Dzhusov (Dzhusov, 2009), H. Hofstede (Hofstede, 2012), E. Osborn (Osborn, 2012) dedicated their studies to organizational culture and human dimension of organization. However, summarizing the groundwork in the abovementioned issues and findings on the challenges of modern creative industry organizations suggest an incomplete research in this area as well as actualize the need of search model types of organizations regarding the demands of the creative organization.

\section{Results}

Requirements of the creative economy challenge a nature of modern organization; it must change its culture from socio-technical to organized (organic). In terms of classical approaches to the theory of organizations, they are ordered and are the functional systems that have certain goals and objectives, as well as people who are both creators and resource of each organization. It is clear that organizations differ in the realization of their goals and tasks, structure, size, technology, level of formalization and information but a common feature of organizations as a classic trend of modern research management is their social and technical nature ${ }^{5}$.

However, today it is evident that the current organization can't be imagined without information technology which covers the whole its system with such relationships as: «Director - Subordinate»; «Director - Director»; «Employee - Employee»; «Organization - Customer.» In such circumstances the ability to use in-

\footnotetext{
${ }^{1}$ Ackoff, R. L. (1981). Creating the corporate future: Plan or be planned for. University of Texas Press.

${ }^{2}$ Ansoff, H. I., \& McDonnell, E. J. (1988). The new corporate strategy. John Wiley \& Sons Inc.

${ }^{3}$ Drucker, P. F. (2008). Management Rev Ed. Zondervan.

${ }^{4}$ Hall, R. (2002). Enterprise resource planning systems and organizational change: transforming work organization?. Strategic Change, 11(5), 263-270.

${ }^{5}$ Pugh D.S., Hickon D.J. Writers on Organizations. PENGUIN BOOKS, 1989. 234 p.
} 
formation (i.e, to have a professional literacy) and constantly learn new things are a major competitive advantage of the organization.

Speaking of trends, it can be noted that the principles of team management change in modern organizations, in other words there is a certain distribution of internal autonomy. The role of oppressive control and authoritarian leadership is reducing. Of course, it is only about the general global trend and not about the absolute process. A support of relationship between groups became a new challenge and ability for managers but it needs the cultural procedures within the organization. Innovation as recognition of the importance of novelty (new ideas, solutions, etc.) can be such factor.

The modern researchers consider the human resources (qualified staff, institutional knowledge) as a main source of competitive advantages of successful organizations. Therefore, organizations can't avoid the need of developing the knowledge and skills of employees, as they affect both the formation of the strategy and its implementation. Acquired skills of staff have an exceptional role in modern management and therefore they should be discussed within modern strategic management.

Thus, the attention of researchers in management began to focus on the human dimension of organization (its organized nature).

During the development of views about the organized nature of the organization it can be brought such model which consists of the following elements (Fig. 1):

Fig. 1

\section{Organization as an organic system}

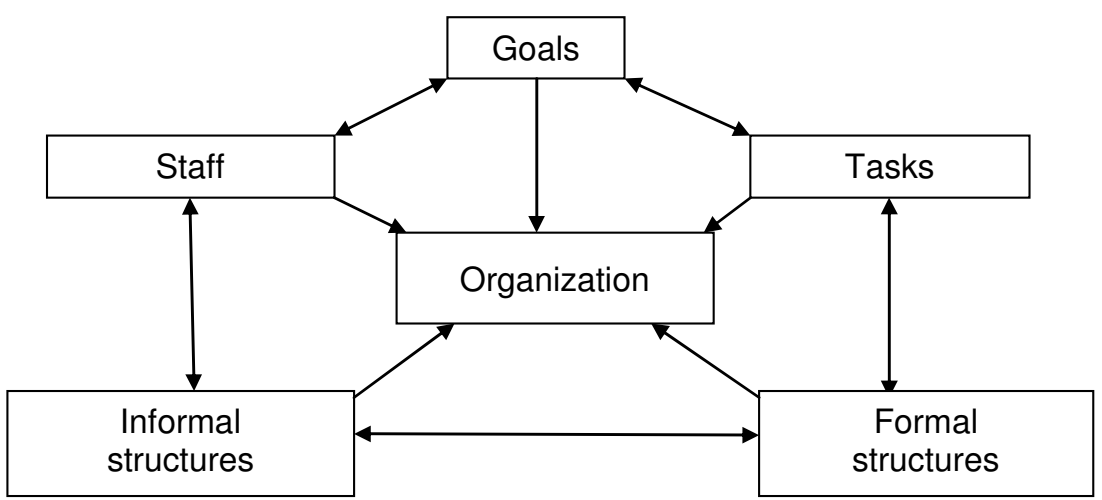


Today the decisive feature of the organization is its culture that largely determines both the internal quality of activity and interacts with the environment. Modern researchers define the organizational culture as a set of dominant values which are characteristic for a particular organization, also a set of norms and rules of conduct, common actions and reactions of its staff including founders (owners), managers and employees. Of course, the organizational culture is not a homogeneous structure (many interpretations and definitions accentuate on its different elements or aspects). For example, one of the models of organizational culture proposed by R. Kilman highlights the following levels of the culture: the visible and perceived artifacts (language, rituals, technology or material objects); the partially visible artifacts (norms and values as a declaration of the approach); as well as the invisible and unconscious artifacts (however, the longest) such as cultural conditions that form the basis of the nature of the relationship between human and organization, the communication between people and so on ${ }^{6}$.

In generally, it is considered that the organizational culture is a theoretical construct which on the one hand, describes the social and technical nature of the organization, on the other hand, describes its complication (complexity), taking into account the interaction of individual elements of organization in the context of internal interpersonal relation and connection with the environment. In this sense, the management researchers linked the "complexity» of organization particularly with knowledge: "Complexity can be defined as a degree of knowledge required for the production system. The degree of complexity of organization can be measured by the level of education of its members: as higher education as higher complexity ${ }^{7}$. However, «... the complexity means at least three things: the number of employed professionals, professional activity and training ${ }^{8}$.

Some researchers define organizational culture as a social and regulatory kind of connection of integrity (holism) of organization ${ }^{9}$. That is why the cognitive, informational and adaptive functions of organizational culture are highlighted. According to these functions, European researches gave off four main types of the culture in the context of the theory of organizational metaphors of the classic theory of the British-Canadian scientist Gareth Morgan: «the mechanical culture» (the organization as a machine), «the bureaucracy culture " (the organization as a political system), "the organic culture» (the organization as an organism) and «the anarchic culture « (the organization as a flux and transformation) (Fig. 2):

\footnotetext{
${ }^{6}$ Kilmann R. Corporate Culture: Managing the Intangible Style of Corporate Life May Be the Key to Avoiding Stagnation // Psychology Today. 1985. \# 19(4). PP. 62-68.

7 Price J.L. Organizational Effectiveness: An Inventory of Propositions. Homewwod, IL.: Richard D. Irwin, 1968. p. 26.

${ }^{8}$ Холл Р.Х. Организации: структуры, процессы, результаты. СПб: Питер, 2001. 512 с. c. 100 .

${ }_{9}^{9}$ De Witte K., Van Muijen J. Organizational Culture: Critical Questions for Researches and Practitioners // European Journal of Work and Organizational Psychology, 1999. \#8 (4). pp. 583-595.
} 
Fig. 2

The main types of the culture ${ }^{10}$

The bureaucracy culture

The high degree of control.

Centralized procedures.

The emphasis on the hierarchical authority.

\section{The mechanical culture}

A big segmentation.

Focus on functional purposes.

Weak interpersonal communication.

The structure which relies on duties
The organic culture

The high interaction of interpersonal communications.

Focus on the common goals.

The structure focused on planning and analysis and not on duties

\section{The anarchic culture}

The high degree of confidence.

Decentralization.

The lower degree of formalization and standardization.

A high proportion of the initiative as a factor of motivation.

The main characteristics of these types of organizational cultures can be characterized:

«The mechanical culture» (the organization as a machine)

Inherent characteristics:

- Every employee is subordinated to only one manager;

- The work is shared between employees with defined roles;

- Each individual is subordinated to the common goal;

- Team is a the sum of individual efforts;

- Managers control the process, employees follow the discipline.

The main principles of management of organizational changes:

- Leaders should provide the changes to the stipulated final state;

- Resistance to changes will always exist but it can be controlled;

- Objectives determine direction of movement and changes and require effective planning and control.

«The culture of bureaucracy» (the organization as a political system)

\footnotetext{
${ }^{10}$ Wspoldzialanie Rywalizacja. Wybrane zagadnia z psychologii kierowania. - Lublin: Towarzystwo Naukowe KUL, 2008. 226 p. 128.
} 
Inherent characteristics:

- Nobody from employees can ignore the policy of the organization;

- In order to be successful, you need to know who has authority and be able to have supporters among them;

- Coalitions (political schedules) are more important than formal organizational structure and working teams;

- The most important decisions concerning the allocation of scarce resources are made by the following principle: "You to me - me to you».

The main principles of management of organizational changes:

- It is necessary to know the political situation, have supporters and understand who will win and who will lose;

- Changes will not be successful if they are not supported by an influential person;

- The effective strategy is a creation of new coalitions and re-discussion the issues in the negotiations.

«The Organic Culture» (the organization as an organism)

Inherent characteristics:

- There is no «best and only» way of formation and management of the organization;

- The basis of success of the organization is information flows between the various elements of the systems and their environment;

- It is important to maximize the coherence of individual, team and organizational needs.

The main principles of management of organizational changes:

- Changes occur only in response to the state of the environment and all employees should be aware of the need to participate in them;

- Reaction to changes in the environment should be chosen from several alternatives and employees should assist in this;

- A strategy of success is a psychological support of subordination to changes in the environment.

«The anarchic culture» (the organization as a flux and transformation)

Inherent characteristics:

- The order arises naturally out of the chaos; organizations have the ability to self-renewal; 
- The organization life is not subordinated to the rules of cause and effect;

- The formal organizational structure (hierarchy, teams) is just one of the many levels of organization life. It needs a constant pressure for the emergence new ways of its activity.

The main principles of management of organizational changes:

- It is impossible to control the changes. They arise by themselves and the main task for manager is to detect flaws and contradictions;

- Stress, pressure and conflicts are important components of internal environment which constantly change it;

- Managers act as helpers; they give people the opportunity to exchange views and to focus on the significant differences of opinion ${ }^{11}$.

It can be assumed that in the future the perfect creative organization with a high level of information will be represented as a certain symbiosis of organic and anarchic culture with overcoming their limitations.

The development of the creative economy (at the macro level) and organization of the information technologies (IT - information technology at the micro level) affect the functioning of individuals, organizations and society. Time of the transformation of industrial civilization to information one appeared along with the increasing importance of information and technologies which ensure its receipt and use. As a result of these changes the information society is emerging which has economic, social and cultural changes under the influence of new technologies.

Considering that the one of the main factors of dynamic IT development is emergence of the information society, it can be affirmed that the new social and economic relations will affect the market creating a digital economy that is based on knowledge and information about the environment of organizations. In general interpretation, the digital economy is equated with a virtual platform where the business activity and transaction are implemented and where there is a creation and change in value of products and services as well as contacts between economic operators. The decisive factors that influence the development of digital economy are use a global knowledge and information as well as modern technology and changes in the way of interaction between the participants of the market economy.

Today's organizations as well as individuals, social and professional formations and national economy, in generally have the impact of globalization processes caused, in particular, by the development of information technology. One of the kind of changes caused by the growth of information is emergence of

\footnotetext{
${ }^{11}$ Гарет Морган. Теория организационных метафор [Электронный ресурс]: http://ibcm.biz/Nauchnye-stati/2011-03-27-16-52-16.html.
} 
«Virtual» organizations where the traditional elements of organizational culture (co-location of staff, simultaneous and continuous communication in the business relationship, etc.) lose their value as being in interests of cooperation in the global information network and where information technologies create the opportunities for dialogue and interaction regardless of distance and borders.

In addition to the use of information technology, the basis of functioning of the virtual organizations is their adaptability namely flexibility and ability to respond effectively to changes of internal and external environment of the organization and transferability that is to say the possibility of functioning outside the traditional geographic and market measurements. Along with this, the important role for the virtual organization is a principle of trust without which it is impossible to imagine its effect as an integrated system, particularly in the internal communications and maintaining contact with the environment, customers, competitors, audience contact and more.

In the context of organizational culture it is difficult to distinguish the information technology as an abstracted factor and describe its impact on changes in formation of the creative culture of the organization. However, the information technology now is a part of integration of the organization; it accompanied the modern organizations at the stage of their origin and was their development environment. At the same time, the new technological possibilities change the environment of organizational functioning; they make it necessary not only to adapt to changes of the environmental conditions and take the responsibility for the activity (or inactivity) but also to create favorable environment factors. In this case it is necessary to talk about the information technology as an external factor which modifies the functioning of the organization. This direct impact is difficult to examine in relation to organizational culture, the process of creation which is lengthy and difficult to control ${ }^{12}$.

In the conditions of globalization economy, the leading IT organizations such as Microsoft or Intel are starting to not only manage the lifecycle of the product but also to teach their consumers while raising their level of education, rigor and nicety and thus to create some new competitive advantages in the global market ${ }^{13}$.

\footnotetext{
12 Холл Р.Х. Организации: структуры, процессы, результаты. - СПб: Питер, 2001. 512 c. cc. 317-318. Pennings J.W. On the Nature of New Technology as Organizational Innovation. Cambridge. MA: Ballinger., 1987. - 520 р. pp. 6, 17-19, 35-37. Джусов О.А. Інноваційний розвиток світової економіки: інвестиційний аспект: моногр. / О.А. Джусов, Н.П. Мешко та ін. Донецьк: Юго-Восток, 2009. 278 с. сс. 9-11.

${ }_{13}$ Building a Solid IT Foundation in any Economy. Windows PC Imaging - The ONE Fundamental of Systems Management.White Paper Series. 9 p. PC Lifecycle Management: Boosting Productivity and IT Efficiency / Intel IT Best Practices Enterprise Mobility and Mobile Business PC July 2012. 10 p.
} 
The creative organizations that operate mainly in the environment of information technologies, taking into account the directions of the structural changes usually are researchers of the organic culture. An important aspect in this case is a communication, in the process of which the considerable changes occur such as internal computer network (Intranet) and e-mail because of the potential of information technology. These changes qualitatively increase the flow of intra-organizational information. They allow limiting the formalization of the transfer of information along the organizational hierarchy and determining the process of creative self-organization structures.

It is clear that the information technology affects the modern organizations through the identification of new opportunities and ways of organization functioning. In the context of the organization as an open system and the development of the concept of situational approach and system management, the researchers of theoretical and practical management thought as important the studying of environment to adapt the organization to the constant changes. When the organization operates in an unstable environment and dynamic competition with continuous demands of technological innovation, the natural development of organization was the creation of a culture where the management style should have been transferable (flexible) and innovative. The creative economy requires promanagement organization; it must create itself the predictable problems and successfully solve them without waiting for changes in today's turbulent environment. Indeed, the internal and external environment of the modern organizations is a chain of continuous change. Administrative and technological innovation should lead to changes in the organizational structure and activities of the organization. The success of functioning of the formations associated with the introduction of the technological innovation depends largely on awareness and understanding of management and so often the need for training and relevant education of managers of the organization is emphasized.

In the context of turbulent (and even shock) changes in the environment, creativity (or innovation) is an essential feature of the organization as well as of staff as a part of organizational system. The strategic vision, initiation of the risk, modeling, experimentation and ingenuity are important elements for the organizations that compete in the creative economy where the information space is dominated.

The challenge and the new ability for leader is to support the coordination of independent business units and it requires new approaches to the internal organizational culture; it should be innovative, that is to say, to recognize the importance of innovation (new planning, making risky actions, etc.). Innovative organizational culture promotes the creativity of human resources and organization as a whole and determines more adaptation of organization to changes in the environment.

Changes in the organizational culture in the context of the IT environment can be presented as an innovative direction. The organic culture that character- 
izes the modern creative organization can be defined as a system of innovative creativity of its participants where the emphasis is on the achievements, competencies, professional development, autonomy, creativity, risk taking, teamwork, openness and trust, all which in strategic management is defined as a strategic vision.

The organization can not circumvent its own attitude to the risk to realize this vision because risk management is the essence of the modern business activity. As said Walter Riston, the former Chairman of the Board "CityCorp / CityBank»: "This is a fact that the business is inherently risk management. It's simple but it is the essence of business". If the organization can protect itself from all sorts of risk nothing wrong will happen to it but it can't develop itself either. The volatility creates a relationship between risk and reward. The challenge is to reduce all observations to the specific real business proposals ${ }^{14}$.

The successful formulation and implementation of strategies which are actionoriented depends on the harmonization of intellectual, interpersonal and leadership factors. There is no simple formula that would work for any organization.

In the context of the above, it can be offered a model of types of organizations, depending on their organic nature, strategic vision and attitude to the risk (Fig. 3):

Fig. 3

The model organic types of the organization nature

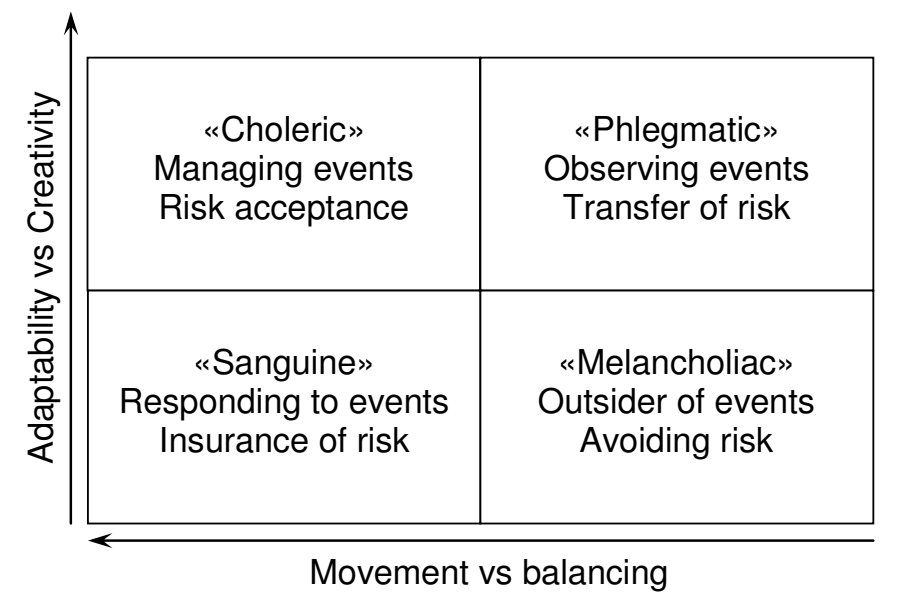
14 Литовченко Б, Толс М. Стратегический менеджмент. Кишинев: EUBAM, 2013.
102 с. с. 31. 
However, a variety of barriers that limit its capacity for creativity and effective use of information technology exist. Thus, one of the most significant reasons that prevent the use of IT strategic resource is the lack of innovative organizational culture and lack of the professional risk managers and analysts.

\section{Conclusions}

In the modern global environment, a new concept of socio-economic development is rapidly growing that brings knowledge, cultural resources and creativity to the forefront of current, post-industrial economy. This innovative sector that has been widely mentioned at the beginning of the XXI century, with the creation of a new and a supernova economy, is called an artistic or creative economy. Requirements of the creative industry challenge a nature of the modern organization - it should change its own nature from socio-technical to the organistical one. The organic culture that characterizes a modern creative organization can be defined as a system of innovative creativity of its participants, with the emphasis on the achievements, competence, professional development, autonomy, creativity, risk-taking, collective work, openness and trust - all these features in a strategic management are defined as a strategic perspective.

Backing of relations between groups becomes a challenge and a new ability for managers that need culture-forming procedures within the organization. It is just this factor that may be recognition of the innovation importance (new ideas, solutions, etc.).

Modern researchers consider human resources (qualified staff, institutional knowledge) to be the main source of competitive advantage of successful organizations. Therefore, any organization cannot avoid the need of knowledge development and workers' skills as they affect both the formation of the strategy and its implementation, as well as require a pro-activity management organization.

Thus, a new organizational culture is being formed that will lead to existence of an ideal creative organization with a high level of information and a certain symbiosis of organic and anarchic cultures with overcoming their limitations.

\section{References}

1. Ackoff, R. L. (1981). Creating the corporate future: Plan or be planned for. University of Texas Press.

2. Ansoff, H. I., \& McDonnell, E. J. (1988). The new corporate strategy. John Wiley \& Sons Inc. 
3. Drucker, P. F. (2008). Management Rev Ed. Zondervan.

4. Kredisov, A. I. (2009). Management as a theory in the historical development. K.: Science of Ukraine. (in Ukrainian).

5. Osborne, A. (2012). Risk management made easy. Bookboon.

6. Pugh, D. S., \& Hickson, D. J. (1989). Writers on Organization. Newbury Park, California, Sage Publications, 234.

7. Kilmann, R. H. (1985). Corporate culture. Psychology Today, 19(4), 62-68.

8. Price, J. L. (1968). Organizational effectiveness: An inventory of propositions. Homewood, III: RD Irwin.

9. Hall, R. (2002). Enterprise resource planning systems and organizational change: transforming work organization?. Strategic Change, 11(5), 263-270.

10. De Witte, K., \& van Muijen, J. J. (1999). Organizational culture: Critical questions for researchers and practitioners. European Journal of work and organizational psychology, 8(4), 583-595.

11. Biela, A. (2008). Styl decyzyjny i stres menedżerski,[w:] Współdziałanie. Rywalizacja. Wybrane zagadnienia z psychologii kierowania,(red.) Z. Uchnast, Towarzystwo Naukowe Katolickiego Uniwersytetu Lubelskiego Jana Pawła II, Lublin-Nowy Sącz.

12. Morgan, G. (2011). Images of organization.

13. Pennings, J. M. (1987). On the nature of new technology as organizational innovation. New technology as organizational innovation, 3, 12.

14. Hall, R. H. (1972). Organizations: Structure and Process. EnglewoodCliffs, $\mathrm{NJ}$.

15. Dzhusov, O. A., Meshko, N. P., Velychko, A. P., Popova, V. A., Stasyuk, Yu. M., Shchypanova, O. V. (2009). Innovative development of the world economy: innovative aspect. Monograph: Donetsk.(in Russian).

16. Building a Solid IT Foundation in any Economy. Windows PC Imaging - The ONE Fundamental of Systems Management. White Paper Series. 9 p. PC Lifecycle Management: Boosting Productivity and IT Efficiency / Intel IT Best Practices Enterprise Mobility and Mobile Business PC July 2012. 10 p.

17. Litovchenko B., Tols M. (2012). Strategicheskij menedjment [The strategic management]. Kishinev: EUBAB, 116.

18. Hofstede, G. (1994). The business of international business is culture. International business review, 3(1), 1-14. 